\title{
TRANSITIONAL POLITICS IN THE DRC The Role of the Key Stakeholders
}

\author{
By \\ Claude Kabemba \\ Claude Kabemba is the Programme Manager Research, Information \\ \& Publication at EISA \\ P O Box 740 Auckland Park 2006 Johannesburg \\ Tel: +27 (0) 11 482.5495; Fax: +27 (0) 11482.6163 \\ e-mail:claude@eisa.org.za
}

\begin{abstract}
Very few observers, either inside or outside the Democratic Republic of Congo (DRC), thought that when Joseph Kabila took over from his slain father he would, within a few years, mobilise the Congolese in a negotiation process that would create the best chance for peace and democracy in the country's history. Political negotiation, which began in Lusaka in 1999 and was successfully concluded in South Africa in 2003 under the leadership of South African President Thabo Mbeki, blew gales of change into the DRC with major consequences for the country. The negotiation process has brought former belligerents together in a government of national unity and created a Parliament that has drafted and adopted the Constitution of the $3^{\text {rd }}$ Republic. The country is now ready for its third democratic election in 44 years. But serious challenges remain before an election can be organised and bring sustainable peace to the country.
\end{abstract}

\section{INTRODUCTION}

The Inter-Congolese Peace agreement known as ' 1 'Accord Global et Inclusive' was signed in Pretoria on 17 December 2002 and endorsed at Sun City on 2 April 2003. The transition process started on 30 June 2003 when the transitional government was installed. The Inter-Congolese dialogue created a new political culture in the history of Congo by establishing a large and inclusive political dialogue. There is no doubt that this was an extraordinary forum. It was the first time the Congolese had sat together since the National Conference which was held in 1991-1992. The transition process that emerged from that conference was halted by President Mobutu.

The Inter-Congolese Dialogue has forced the Congolese to make substantial compromises in relation to the redistribution of political power during the transition. It has also introduced the culture of cohabitation in government institutions by 
different political forces and has brought peace to a large part of the territory. But what are the prospects for a successful transition?

In terms of the Peace Accord, the transition was to end on 30 June 2005 but allowance was made for two possible six-month extensions if this were recommended by the Independent Electoral Commission to a joint session of the National Assembly and the Senate (Transitional Constitution Art 196). Forty-four groups, including armed factions, exiled political figures, and civil society groups signed the Final Act at Sun City in South Africa (Star 3 April 2003). This transition, if allowed to reach its logical conclusion, the holding of free and transparent elections, should produce the foundation on which to build a culture of democracy. One key objective of such elections will be to restore legitimacy to government. The Democratic Republic of Congo (DRC) has not had a legitimate government in the past 43 years. During this period the state collapsed, producing one of the most dysfunctional entities on the continent.

Since Sun City, the country has made significant strides in implementing the key requirements of the accords with the main structures now in place. These are a Presidency comprising a president and four vice-presidents representing all the major political tendencies; a Parliament with two chambers - the National Assembly and a Senate; and five institutions for the support of democracy: the Independent Electoral Commission (IEC), the Truth and Reconciliation Commission (TRC), the High Authority of the Media (HAM), the Anti-Corruption Commission (ACC) and the Human Rights Commission (HRC).

However, it is one thing to set up institutions and structures and quite another to make them functional. Only two of the five institutions, IEC and HAM, are operational.

DiPalma (1990) proposes the following preconditions for successful democratic transition:

- Minimal divisions within the forces of old regimes and the opposition. This ensures that a dialogue can be conducted and extremists can be marginalised.

- The vital interests of all participants must be guaranteed in the transition period and in the new constitution. Thus, previously recalcitrant forces come to believe that a change of government will not threaten them.

- The balance of international forces and support must favour democratising forces over authoritarian forces and all participants must be offered incentives to compromise.

A successful transition would initiate a process of national reconciliation and state building. At present the conditions are being put in place incrementally to ensure that democratic elections take place at the end of the transition. But does the DRC have the capacity, the visionary leadership, the political will and the resources to move towards a democratic society? This work tries to answer this critical question 
by reflecting on the strengths and weaknesses of key stakeholders in the process. It will look at the following actors: the executive, Parliament, political parties, civil society, the media and the international community. These stakeholders were chosen because of their critical importance to the transition process. Other important stakeholders are the army and the justice system, which are not looked at here except in relation to the first set of stakeholders.

\section{The Presidency During the Transition}

The Inter-Congolese Dialogue provides for a system, commonly know as the $1+4$ formula, whereby the president is seconded by four vice-presidents. The formula is unique and has never been tried before. The Peace Accord retained Joseph Kabila as President during the transition, seconded by Jean Pierre Mbemba, chairman of the Movement for the Liberation of Congo (MLC); Azarias Ruberwa, leader of the Rally of Congolese for Democracy (RCD); Yerodia Ndombasi, representing the former government; and Zahidi Ngoma, representing the non-armed opposition. Each vice-president has a commission under his responsibility, as shown in Table1.

The challenge for the transition has been how to ensure a smooth working relationship between the president and each of the four vice-presidents on the one hand and between the four vice-presidents on the other. The key area of contestation between the leaders of the different groups was not as much what they offered in terms of change as the battle for the presidency. The creation of five presidential positions arose out of the competition between President Joseph Kabila and his two Vice-Presidents, Jean Pierre Mbemba and Azarias Ruberwa. The three have not enjoyed a smooth relationship, especially during the early stage of the transition. There has been continuous tension between the President and the two former rebel leaders.

However, there has been no tension between Kabila and other two VicePresidents, with whom he shares a close relationship. Ndombasi comes from Kabila's political family and Ngoma's nomination received great political support from Kabila. The Kabila government is said to have played a key role in ensuring that Zahidi Ngoma, a close ally, leads the non-armed opposition group. In line to represent this group were Nzuzi wa Mbombo, leader of the Mouvement Populaire de Revolution (MPR) and Etienne Tshisekedi, leader of the Union Pour la Democratie et le Progrès Social (UDPS).

The 1+4 formula encapsulates the value of inclusiveness on which the entire negotiation process from the Lusaka Peace Accords to the Pretoria Peace Agreement was founded. The inclusive nature of the negotiations marks an important change in the political thinking of the Congolese. For the first time they were coming to terms with a situation in which different groups could work together to achieve a common purpose - peace and political stability. Despite the problems this system has experienced and continues to experience, one of its great benefits for the DRC is that the Congolese leadership has been introduced to the notion that 'in a 
democracy no one can choose himself, no one can invest himself with power to rule, and therefore no one can give himself unconditional and unlimited power' (Breytenbach 2003, p 65). Only the entrenchment of these values will set the country on the road to sustainable democracy and development.

\section{Table 1}

\section{Vice-presidents and Their Portfolios}

\begin{tabular}{|l|l|}
\hline Name & Portfolio \\
\hline Jean Pierre Bemba (MLC) & Economy and Finance \\
\hline Azarias Ruberwa (RDC-Goma) & Politics, Defence and Security \\
\hline Yerodia Ndombasi (ex-government) & Development and Reconstruction \\
\hline Zahidi Ngoma (non-armed opposition) & Social and Cultural \\
\hline
\end{tabular}

Although the transitional Constitution defines the role of the president and gives specific roles to each vice-president, it does not clearly articulate the working relationship between the five and how decisions are to be taken. In fact, a closer look shows that there is a tendency for some vice-presidents to behave as did prime ministers during the First Republic. Insiders report the existence of serious tensions and suspicions between the president and the two vice-presidents from the former rebel movements, the MLC and the RDC.

It is difficult to say precisely what kind of system - presidential or parliamentary - currently exists in the DRC. The major threat to the transition, if there were to be one, would probably come from within the Presidency. As Henri Boshoff (2004) suggests, 'The RCD and MLC in particular are worried about the growing independence displayed by Joseph Kabila in the decision-making process and fear that their prerogatives are being undermined by the Presidency. ${ }^{\prime 1}$ The weakness of the $1+4$ formula is that the four vice-presidents do not have a defined role. It will come as no surprise if the tension referred to above degenerates into total chaos closer to elections as major government decisions will be made by the president and his vice-presidents to enhance their standing during the election campaign. Every party in the government of transition has tried to outmanoeuvre the others by using every opportunity, even state resources, to advance its interest. But what has been exceptionally surprising is the fact that everyone concerned accepts that there is no option but to work with the $1+4$. All Congolese accept that despite the imperfection of the $1+4$ solution and its conflictual nature, it must be allowed to continue. This is a sign that there is a level of political maturity in the

1 See Henri Boshoff's report on a trip to the DRC from 6 to 11 July 2004 available on line at www.iss.org.za 
DRC. But there are concerns among ordinary Congolese that the transition process is very slow and political leaders are being accused of deliberately delaying it. For this reason the Congolese Catholic Bishops have called for sanctions against anybody who violates the Constitution and for a strong justice system to accompany the formation of the government

It seems it is the management of the Presidency that will make or break the transition. A good relationship between the president and his vice-presidents and between the vice-presidents themselves could influence the resolution of other difficulties facing the transition, especially the integration of the armed forces. But a closer observation of the behaviour of some of those in power simply reflects the historical political culture left behind by Mobutu and his clique whereby 'the state remains a major source of capital accumulation and the fulcrum of social privileges (Adejumobi 1997, p 126)'. The new elite continues to see the state as 'the major avenue of upward mobility, status, power and wealth (Callaghy 1986, p 36)' and not as an opportunity to serve the community. If this is allowed to continue there is no hope for a better future for the Congolese. Indeed, this mode of operation reflects Max Weber's conclusion that 'the way of doing politics is not to live for it, but to live from it (Adejumobi 1997)'. As Joseph Ayee convincingly put it, 'the persistent development crisis and the recent phenomenon of failing states are due in part to poor leadership; leaders who are not committed to the development of their societies and who lack honesty and commitment to democracy'.

Unlike South Africa, which was fortunate to have had Nelson Mandela and F W de Klerk, there has, in the Congo, been a lack of the necessary leadership to seize the opportunity to fast track the transitional process. Mandela and De Klerk understood the situation of their respective political organisations and, realising that no one organisation was likely to win, took difficult decisions, some of them very unpopular with their organisation, throughout the negotiation process.

The Congolese appear to be unlucky on this score - as one executive member of the RCD puts it, 'The fundamental problem in the DRC is the deficit of transitional leadership at the pyramid of the government' (Interview, civil society group, Kinshasa November 2003). The slow process and the tension emanating from the presidency sent negative signals to the nation and most Congolese remained sceptical about the transition until the adoption of the Constitution. For them, there seemed to be no difference between the pre-Mobutu and post-Mobutu periods.

Individuals in government are accused of being interested only in their political survival and doing everything possible to prolong the transition process. For example, when the transitional government presented its programme for the first time on 2 December 2003, it was vague about the question of elections. In fact, the plan of action did not emphasise elections as a priority. There were no concrete proposals for government financial support for the electoral process. This came as a disappointment to citizens, who see elections as the only hope they have. The government's uncommitted attitude to elections also influences donor commitment. Donors have been reluctant to make good their financial pledges on the grounds 
that there is a lack of genuine commitment by political leaders to elections and there is no well-structured government that can be trusted with the finances.

\section{The Parlament of Transition}

The Parliament is bicameral, with a National Assembly and a Senate comprising 500 (Table 2) and 120 (Table 3) members respectively. The way Parliament discharges its duties will influence the democratisation process in the DRC.

Parliament consists of the five main groups or composantes and three small groups or entities that participated in the Inter-Congolese Dialogue and signed the final agreement (Table 3). ${ }^{2}$ The composantes are constituted by the former government, the two former rebel movements - the RCD and the MLC, the non-armed opposition and civil society. The first three groups, which fought each other, hold the balance of power. The non-armed opposition and civil society groups are weak and are aligned to the first three. The three 'entities' are the Rassemblement Congolais pour la Démocratie, Mouvement de Libération (RCD/ML), the Rassemblement Congolais pour la Démocratie, National $(\mathrm{RCD} / \mathrm{N})$ and the Mai-Mai. They are largely insignificant but may play a critical role when alliances are formed in Parliament around specific issues.

The National Assembly has three main functions - to legislate; to exercise control over government, public enterprises and the civil service to monitor the implementation of the resolutions of the Inter-Congolese Dialogue and to adopt the Constitution to be submitted to the referendum (Constitution of Transition Art 98).

Table 2

Composition of the National Assembly

\begin{tabular}{|l|c|l|c|}
\hline Main Stakeholders & No.of MPS & Entities & No. of MPs \\
\hline Armed Opposition & & & \\
\hline RDC/Goma & 94 & & 10 \\
\hline MLC & 94 & Mai Mai & 10 \\
\hline Ex-government & 94 & RCD /ML & 5 \\
\hline Civil society & 94 & RCD/N & 5 \\
\hline Non-Armed Opposition & 94 & Small entities & 30 \\
\hline Total & 470 & Total & \\
\hline
\end{tabular}

2 There are groups that participated but are not part of this Parliament. For example, the G14 and UDPS are out of Parliament. But in the case of the G14, while the decision was that the group will remain out, some of its members joined other groups and are in Parliament today. 
The role of the Senate is to mediate political conflict among different institutions. It also charged with writing the draft Constitution (Constitution of Transition Art 98). In general, Parliament is weak because of the social and economic crisis and the political circumstances under which it was set up. This distribution of MPs and Senators was agreed upon at Sun City and reflects the representation of the different delegations to the talks.

\section{Table 3}

\section{Composition of the Senate}

\begin{tabular}{|l|c|}
\hline Main Stakeholders & Number of Senators \\
\hline Government (PPRD) & 22 \\
MLC & 22 \\
\hline RCD & 22 \\
\hline Civil society & 22 \\
\hline Political opposition & 22 \\
\hline Entities & \\
\hline Mai-Mai & 4 \\
\hline RDC/ML & 4 \\
\hline RCD/N & 2 \\
\hline Total & $\mathbf{1 2 0}$ \\
\hline
\end{tabular}

\footnotetext{
* Main stakeholders were the key Groups to the Inter-Congolese Dialogue who took the larger share of Parliamentary seats.

* Entities Were the smaller groups at the Inter-Congolese Dialogue.
}

\section{WOMEN's REPRESENTATION IN PARLIAMENT}

There are only 62 women in the National Assembly of a total of 500 members. The Senate has only three women out of 120 . This biased representation goes against the spirit of the Lusaka Accords, which put the threshold at 30 per cent in line with the Southern African Development Community (SADC) protocol. Sun City did not take care of gender balance either in the National Assembly or the administration.

The same lack of representation applies to civil society groups. Of the 68 who were present at the negotiations only 14 are in Parliament. This is an unfortunate situation given that the Constitution of transition clearly emphasises genderbalanced representation in Parliament. It seems that in the Congo the concept that political power belongs to men is culturally entrenched - the under-representation of women cuts across all groups represented in government. The future electoral system must be designed to deal with this issue and political parties must be encouraged to increase the number of women in positions of leadership. 


\section{PARLIAMENT'S ACHIEVEMENTS}

The two houses of Parliament, the National Assembly and the Senate, work through eight commissions:

- Political, administrative and legal commission, led by the non-armed opposition

- External Relations commission, led by the RCD/ML

- Economic and finance commission, led by the former government

- Defence and security commission, led by the Mai Mai

- Women, family and youth, led by the MLC

- Support to democracy commission, led by civil society

- Social and cultural commission, led by the RCD

- Reconstruction and development commission, led by civil society

Parliament got off to a slow start because of logistic and budgetary constraints and members went for months without being paid. But the work of Parliament is also behind schedule because of the government's wrangling. The slow process affected the calendar for the execution of the transition and resulted in the postponement of the elections from June 2005 to 2006.

However, despite the delays, Parliament has been able to achieve most of its targets. Laws have been passed and the draft Constitution of the Third Republic was adopted on 16 May 2005. With the Constitution adopted, it will now be easy to draft electoral laws to pave the way for democratic elections. The content of the new Constitution clearly shows how the new state will begin to depart from the character of previous states under Mobutu and Laurent Kabila. For example, the Constitution prescribes two terms for the president, it introduces gender parity in all state structures and there seems to be a clear separation of power between the executive, the legislative and the judiciary. It also creates the position of Prime Minister, a move that will dilute the power of the President, which has been the source of most of the problems of the DRC.

There is also a move to decentralise the state and, although the devolution of power to the provinces will be incremental, this is a positive step for this territory, which is the size of Eastern Europe. The new Constitution proposes to increase the number of provinces from 11 to 26 .

\section{Political Parties}

Most political parties are new and have no ideology. For most of them the main focus is how to access power, even though they have no clearly articulated programme of how to use that power once they have it. The problems political parties are facing are not peculiar to the DRC but reflect similar characteristics to parties in other countries. They are badly structured and have very weak financial 
bases and they remain very ethnically and regionally orientated. Generally no political party can claim to have a monopoly on political mobilisation and although parties such as the PPRD and the UDPS can presumably claim to have a presence in all provinces the extent to which their structures there are operational is not very clear.

The theoretical approach to how political parties should function cannot be applied directly to the DRC. The internal disorganisation, absence of ideology and weak structure suggest that the country does not have political parties as we know them in other parts of the world.

It is estimated that the DRC may have a total of 443 political parties. But only eight of these - the MPR / FP, the Parti Lumumbiste (PALU), UDPS, PPRD, the Parti Démocrate Social Chrétien (PDSC), PCR, RCD and MLC - seem to have some visibility.

All the political parties tend to have very weak internal structures and a limited connection with their supporters. They also face financial difficulties which limit their ability to operate and communicate with their members. The Congolese people in general do not know the ideology or philosophy of the parties to which they belong, not surprisingly, since even the constitutions of the parties are not easily accessible to their members.

In other SADC countries such as Mozambique, Namibia and South Africa, which have gone through a similar process former rebel movements have made a smooth transition to relatively well-structured political parties. This is due primarily to long years of struggle during which they built an ideological base which allowed them to enter the multiparty game on a much stronger footing. Even for a relatively weak group like Renamo, under the leadership of the low-rated Alfonso Dlakama, in Mozambique made a spectacular transformation. In the DRC, former rebel groups, although they are political parties on paper, are failing to transform and this is one factor hampering the transition process.

The transition cannot proceed with unstructured political parties which have no clear and well-articulated ideology. Political ideology is a system of ideas a party espouses to explain a society and either to justify or to criticise what is happening and uses as a basis for action to maintain and transform the society. Political ideologies are very important to the development of humanity. The hypotheses, models and theories they propose are sometime very important to the direction societies take and the way they are constructed. All this is lacking in the DRC. By way of illustration, no political party has taken time to reflect on the following issues:

- The geographic, demographic, religious and ethnic context in the DRC. The DRC is among the biggest states on the continent, the others being Nigeria, Sudan, Angola, Ethiopia and South Africa. Of these, all except South Africa are faring badly. Does the size of a country have an impact on its performance? What kind of political system would address 
simultaneously the problems of size and good governance? How do you ensure that all the different ethnic groups are represented in whatever system of governance is put in place?

- The political, economic and security policies adopted by the transitional government. What kind of electoral system and state (unitary or federal) does the DRC need? In a country destroyed by years of mismanagement and war what kind of macro-economic policy would balance the internal demands of social delivery and the demands of globalisation. Questions of privatisation, trade relations, and debt and development aid are not being addressed.

- The role of outsiders, including other African states, criminal networks, the diaspora, and westerners, their effect on the country's trajectories and the threat posed by internal and external groups to the integrity of the state.

\section{PARTY FUNDING}

One threat to the transition process could be the funding of political parties and its ability to create a level playing field. A party cannot function without a solid financial base. There seems to be a great disparity between the financial fortunes of political parties in the DRC and this could also influence the way they campaign during elections. In a society where poverty is rife, victory could go to whomever has the upper hand in terms of finances. For instance, the armed groups struggling to transform into political parties have access to resources in the areas under their control and can use them to build a strong financial support system. The PPRD, MLC and RCD have no money although individuals within them do. But it seems the leaders of these parties are not interested in funding the parties. The leaders, as they did during the Mobutu regime, use the revenue to enrich themselves.

Other parties which have been in existence since that Mobutu regime - the MPR, UDPS and PALU - remain divided along ethnic lines and, although they are well known, they draw most of their support from their leaders' province of origin and face serious financial difficulties in making a significant contribution to the transitional process. The MRP, Mobutu's party, should be the most stable financially since it includes in its ranks some former ministers and Mobutu's children, who are known for having indulged in corruption and the theft of state resources in the past. Most of them are not prepared to sponsor the party although they want it to bring them back to power.

The last group of political parties has no membership base and faces both organisational and financial difficulties. The parties are so insignificant that they are marginalised in the transition process and will simply disappear when the election campaign starts and join the bigger, better-known parties. 
The question that arises is whether party funding should be regulated or not? Regulated funding could result in political interference in Congolese politics from external elements, as happened during the war when external powers and multinationals played an important role, unregulated funding would be preferable in the current environment in the DRC. But if external funding becomes an imperative, an election pool fund could be created to distribute funds equally among all qualified political parties. Before the elections, the challenge would be how to distribute the money to the number of parties that are expected to enter the political race and how to limit this number.

\section{INTER-PARTY DEMOCRACY}

The challenge of democratising political parties in the DRC remains real. The difficulties the parties are experiencing include the inability to transform into genuine political parties that can spearhead the democratisation process. A lack of democracy within the parties is biggest problem. The leaders have an enormous amount of control over their parties, which are experiencing a situation akin to 'dictatorship by their own leaders'. The fact that parties are 'undergoing construction' needs to be taken into account. Generally, it seems that members do not participate in the 'daily life' of their parties, which have top-down structures whereby party leaders decide on all matters. Looking at the Lesotho experience Khabele Matlosa (2003, p 85) offers a crucial lesson for the DRC, stating that since parties are the key actors in the democratic process and key agents for the running of state machinery, their internal management structures will need to be adequately democratised and the success or failure of this democratisation process will be reflected in the way primary elections are conducted.

\section{CiviL SOCIETY}

By its nature, civil society can contribute to building and consolidating democracy by fostering political pluralism, engendering democratic values and enhancing political participation. The democracy discourse on the continent has been marked by a critical probe into the state and role of civil society organisations in the governance process (Sachikonye 1995, p 400). A question posed in societies in transition is whether pro-democracy non-governmental organisations (NGOs) influence the process and the design of transitional policies and laws?

There is a vibrant civil society in the DRC with a multitude of organisations including human rights groups, women's groups and youth groups. But they are not well organised and do not play a balancing role to provide a bulwark against malgovernance. They lack the internal organisation that would give them the capacity to foster participation and influence state decision-making. A further problem is that their multiplicity does not also mean they are autonomous and this lack of autonomy reduces their effectiveness in influencing the behaviour of 
politicians. Civil society in the DRC has always been politicised and divided along ethnic lines and until recently the most vibrant manifestations of civil society were in Kinshasa. But with the war in the east of the country that area has also developed strong and vibrant civil society groups. During the negotiations Kinshasa's civil society expected to influence the process but because the process was intended to be inclusive of a range of regional and political interests, the number of representatives from Kinshasa's civil society groups was reduced (manipulated) in favour of groups from the east of the country.

One of the greatest achievements of the negotiation in the DRC is to have included civil society groups at all, a recognition of civil society's struggle for democracy since Mobutu. But what the negotiation did was further politicise civil society by including its influential members in government institutions, Parliament and the Senate. This has further crippled state-society relationships. Civil society, which was politicised and sidelined under Mobutu and Laurent Kabila, has emerged not as a watchdog but as a strong contender for political power. Like those of political parties, the internal structures of civil society organisations are undemocratic. All the groups have presidents who set the rules and the replacement procedures. If they are accountable at all, it is to donors. Even here, receipts for work done are frequently faked. Some NGOs, like many political parties, are simply 'briefcase institutions'.

During and after the Inter-Congolese Dialogue, civil society leaders positioned themselves in such a way that they cannot be ignored as serious contenders for political power. The importance and strength of civil society does not simply come from the text of the Accords, which allows it to be part of the transitional institutions, it also comes from its provincial and ethnic positioning. Civil society's ethnic and political character is stronger than its watchdog mission and because political leaders have come to realise that they ignore its presence at their peril civil society groups and individual representatives are treated as political actors. The result is that it seems politicians have been given carte blanche to implement a transition to their own liking.

In other countries on the continent the independence, strength and pluralism of civil society and its ability to unite in a broad front, has been a critical factor in shaping democratic change. In the DRC, civil society groups, by participating in the distribution of political power, have lost their legitimacy.

\section{The InTERnATIONAL COMMUNity}

The international community has played a key role in taking the DRC where it is today. Ethienne Tshisekedi, the leader of UDPS, suggests that it is time to stop criticising Europeans who are helpful although they also, when given the opportunity, exploit weaknesses to promote their own interests (Interview, Kinshasa November 2003). The involvement of the international community is crucial to the success of the DRC's transition, before, during and after the elections. 
The coming elections are expected to be funded from outside - not necessarily the best option but one imposed by the current socio-economic and financial situation of the country which would not allow it to fund its own elections. Foreign governments and international institutions are involved at different levels in the transition process with some having sent experts to support the state institutions and electoral body. The French, the Belgians and the South Africans, for example, are devoting their time to training the country's security forces. La Mission de l'Organisation des Nations Unies en République Démocratique du Congo (MONUC) is involved in peacekeeping. While the contribution thus far has been beneficial, gaps still remain in donors' intervention in the DRC and it seems they have not learned from previous experiences.

While it is important to focus on keeping the peace donors also need to look seriously at issues which would contribute to cementing that peace. One key issue is the planning and financing of elections. The holding of elections is an urgent matter. As Willian Lacy Swing, the head of MONUC in the DRC, put it in an interview with the author (November 2003), the transition will be a failure if it does not produce a democratic dispensation. For this reason MONUC follows the preparations for the elections closely. Its election support structure, led by Swing's deputy with three electoral assistants, supports the Independent Electoral Commission and coordinates the work of donors (Interview with the Head of MONUC November 2003. Another concerned organisation is a committee of foreign ambassadors called Le Comité International d' Assistance à la Transition (CIAT), whose role is to monitor and evaluate the transition process. But in general the international efforts are ad hoc undertakings governed by few consistent principles, norms, rules, or established procedures. Such initiatives are carried out by a host of autonomous actors, including donor governments, the UNDP, NGOs such as the International Foundation for Electoral Systems (IFES), the Electoral Institute of Southern Africa (EISA) and the National Democratic Institute (NDI). All these international actors believe that if the government of transition is left alone it might not be able to move the process forward fast enough.

The donor community has pledged financial assistance to the electoral process, but the framework for designing, coordinating and delivering such assistance remains woefully fragmented and under-institutionalised. It seems that donors did not have an agreed strategy, based on a common vision. Another worrying point is that donors have postponed efforts to plan aid intervention as happened in Afghanistan and is projected for Iraq.

Experience has shown that successful donor support for sustainable peace and reconstruction is based on resolving the following key challenges (Patrick 1999, p 35):

- The mobilisation of resources

- The deepening of institutional reform

- The harmonisation of aid conditions 
- The coordination of assistance locally

- The enhancement of recipient capacities

- The promotion of accountable aid delivery and implementation

Donors argue that it is difficult for them to design support mechanisms when they do not know what kind of elections will be organised. In this way they have put the ball in the court of the Congolese, who have been very slow in passing the necessary electoral laws. The European Union will bear most of the cost. Most pledges have been in the technical area of elections but very little has been said about the logistics.

The donors' concern is that they cannot fund all aspects of the elections, particularly the salaries of electoral officials, who are considered to be civil servants. This must be the responsibility of the government and they have requested that government contribute to the financing of the elections. One member of civil society estimates (Interview, Kinshasa November 2003) that the Congolese government could put together up to US\$100-million a month for the elections (and this does not include the money that goes into private pockets). Since there is no major social spending from government, there is no good reason to argue that the state cannot fund the elections, whose costs are estimated at US\$ 300-million

\section{CONCLUSION}

The transitional process in the DRC is happening under very difficult socio-economic and military circumstances, with problems including the collapse of the state, the hostilities that continue in the east of the country, political corruption, economic stagnation, ethnic clashes, and the misuse of mineral and ecological resources. A transition that will pave the way for democratic elections is the only hope for a stable DRC. Despite the disappointment engendered by the slow progress being made in this direction there is a need to ensure that the process continues and is founded on the values acquired at Sun City: inclusiveness and negotiation, an ethos of reconciliation and nation building and tolerance.

The Congolese people have matured and are not prepared to be held hostage indefinitely. People are becoming increasingly demanding, as demonstrated by the actions of 3 June 2004 when they took to the streets in protest against the renewed violence in the east of the country and demanded a speedy end to the transition. The $1+4$ formula, despite its flaws, is an important mechanism for bridging the country's diversity. There is also hope created by the unanimous position of the international community through the CIAT that elections will take place within the timeframe agreed upon at the Inter-Congolese Dialogue.

However, in Congo there is no institution that enjoys popular trust. The undue influence of the executive on other institutions such the judiciary, Parliament, the military and the Chapter 9 institutions poses a threat to the consolidation of the current process and will pose an even greater threat in the future if it is not attended to. 
The existence of a vibrant but ineffective civil society is a serious weakness in the entire process. For civil society organisations to play their role efficiently, they must themselves be democratic and motivated by broader social concern. Civil society in the DRC must consider instituting non-statutory self-regulatory mechanisms to engender a spirit of trust from government. It is incumbent upon civil society, especially the so-called NGOs, to take a critical look at itself and put its house in order if its criticism of others is to acquire moral force and credibility. Self-regulation is also the best way of keeping government interference at bay.

Donors must make strategic interventions to support the transition process. The first phase has been successfully completed with the drafting and adoption of the Constitution of the $3^{\text {rd }}$ Republic. Now there is a need to ensure that the war does not return and elections do not become a source of discord. The international community can help speed up the process by offering financial and logistical support to the institutions of transition. A semblance of a state must be created in the DRC. A national army that can protect the integrity of the new state is badly needed, a professional police that respects human rights must be trained as a matter of urgency and a credible justice system is also needed to support the transition. The challenge is to avoid a political vacuum at any time during the process.

\section{- REFERENCES —}

Adejumobi, Said. 1997. 'The Two Political Parties and the Electoral process in Nigeria: 1989-1993'. In Nzongola Ntalaja and Margaret Lee (eds). The State and Democracy in Africa. Zimbabwe: African Association of Political Science. Ayee, Joseph. Forthcoming. 'Leading Large States'. In Jeffrey Herbs and Greg Mills 'Africa's Big Dysfunctional States'.

Breytenbach, W. 2003. 'Democratic Transition in the SADC Region'. In Bobo Immink, Samson Lembani, Martin Ott and Christian Peters-Berriers. From Freedom to

Empowerment: Ten Years of Democratisation in Malawi. Malawi: Konrad Adenauer Foundation.

Callaghy, Thomas. 1986. 'Politics and Vision in Africa: The Interplay of Domination, Equality and Liberty'. In Patrick Chabal (ed). Political Domination in Africa. Cambridge: Cambridge University Press.

Dialogue National. 2004 No 194. 'Washington promet 108 millions de dollars pour soutenir la transition en RDC', Tuesday 7 September.

Di Palma, G. 1990. To Craft Democracies. Berkeley: University of California Press.

Matlosa, Khabele. 2003. 'The Electoral Process and Democratic Governance in Lesotho: Lesson for the Democratic Republic of Congo. Journal of African Elections 2(1).

Mumba, Marcel. 2003. 'Idéologies des parties Politiques Congolais au regard des enjeux électoraux de l'an 2005'. The Scrutin 35.

Sachikonye, L. 1995. 'Civil Society, Social Movements and Democracy in Southern Africa'. Innovation 8(4). 
Star, The. 2003. 'Historic Part rings in new period for the DRC', 3 April.

Stewart, Patrick. 1999. 'The Donor Community and the Challenge for Post conflict Recovery'. In Shepard Forman and Stewart Patrick. Good Intentions: Pledges of Aid for Post conflict Recovery. United Kingdom: Lynne Rienner. 